\title{
TOXICITY OF SOME CONVENTIONAL, NONCONVENTIONAL INSECTICIDES AND THEIR MIXTURES AGAINST COTTON LEAF WORM, SPODOPTERA LITTORALIS (BOISD.) (LEPIDOPTERA: NOCTUIDAE) IN COTTON FIELDS
}

\author{
BARRANIA, A. A., M. A. EL-BESSOMY and M. H. M. EL-KHAWALKA
}

Plant Protection Research Institute, Etay El-baroud Agric. Res. Station, ARC, Egypt.

(Manuscript received 19 December 2012)

\begin{abstract}
Toxicity of chlorpyrifos-methyl, methomyl, chlorantraniliprole, thiamethoxam and novaluron at two low concentrations $(1 / 2 \& 1 / 4$ field recommended rates) and their binary mixtures were tested against $4^{\text {th }}$ instar of Spodoptera littoralis larvae at two cotton growing seasons 2011 and 2012. Percent mortality of chlorpyrifosmethyl, methomyl, chlorantraniliprole, thiamethoxam and novaluron at $1 / 2$ field rates on 2011 cotton season, was 22.5, 27.5, $17.5,12.5$ and $12.5 \%$, respectively after 24 hours, while it was $72.5,52.5,90.0,57.5$ and $57.5 \%$, respectively after 48 hours. Percent mortality at $1 / 4$ field rates, was $17.5,17.5,22.5,2.5$ and $27.5 \%$, respectively after 24 hours, while it was $42.5,30.0,85.0$, 50.0 and $50.0 \%$, respectively after 48 hours. Concerning mortality percentage of chlorpyrifos-methyl, methomyl, chlorantraniliprole, thiamethoxam and novaluron at $1 / 2$ field rates on 2012 cotton season, was 32.5, 32.5, 27.5, 20.0 and $20.0 \%$, respectively after 24 hours, while it was $72.5,70.0,50.0,57.5$ and $62.5 \%$, respectively after 48 hours. Percent mortality at $1 / 4$ field rates, was $27.5,27.5,20.0,12.5$ and $30.0 \%$, respectively after 24 hours, while it was $67.5,50.0,52.5,40.0$ and $62.5 \%$, respectively after 48 hours.

During 2011 cotton season, all tested insecticide mixtures have antagonistic effects (cotoxicity factors $<0$ ) after 24 and 48 hours, except for chlorpyrifos-methyl (1/2 F.R)/chlorantraniliprole (1/2 F.R) mixture, chlorpyrifos-methyl (1/2 F.R)/thiamethoxam (1/2 F.R) mixture and chlorpyrifos-methyl (1/4 F.R)/chlorantraniliprole (1/2 F.R) mixture exhibited potentiation effects (cotoxicity factors were $+6.3,+7.1$ and +7.1 , respectively), after 24 hours. Methomyl (1/4 F.R)/thiamethoxam (1/4 F.R) mixture exhibited potentiation effects (cotoxicity factors was 12.5), while methomyl (1/4 F.R)/novaluron (1/2 F.R) mixture exhibited additive effects (cotoxicity factors was $0)$. At 2012 cotton season, after 24 hours, only one [chlorpyrifosmethyl (1/2 F.R)/chlorantraniliprole (1/4 F.R) mixture] of 24 binary mixture tested showed potentiation effect. While the majority, 22 mixtures exhibited antagonistic effects, and only one exhibited additive effects [chlorpyrifos-methyl (1/2 F.R)/chlorantraniliprole (1/2 F.R) mixture]. After 48 hours, all tested insecticides mixtures have antagonistic effects.
\end{abstract}




\section{INTRODUCTION}

The cotton leafworm, S. littoralis is a serious lepidopteran pest. In Egypt, larvae causing considerable damage to cotton plants as well as more than 29 hosts from other crops and vegetables (Pluschkell et. al., 1998 and Korrat et. al., 2012). The intensive use of broad-spectrum insecticides against $S$. littoralis has led to the development of resistance to many registered pesticides use for its control (Aydin and Gürkan, 2006, Smagghe et. al., 1999). Recently, the uses of conventional insecticides applications are not recommended to reduce the environmental hazards and conserve natural enemies population. Meanwhile, the use of new insecticides which are effective, safer for human and negligible effects on ecosystem. Some of these approaches are insect growth regulators, neonicotenoid and anthranilic diamide insecticides alone and their mixtures.

Chlorpyrifos-methyl and methomyl are insecticide widely used in agriculture. Its induces acute cholinergic poisoning in mammals by inhibiting acetylcholinesterase (AChE) activity reversibly with a subsequent accumulation of acetylcholine at peripheral and central nervous systems. Active ingredients of chlorpyrifos-methyl and methomyl have been classified as highly and slightly hazardous pesticides, respectively (WHO, 2010).

Chlorantraniliprole is a new anthranilic diamide insecticide, which effectively control pest insects belonging to Lepidoptera, Coleoptera, Diptera and Hemiptera, and has been shown to be effective against insecticides that have developed resistance to older classes of chemistry. Chlorantraniliprole causes feeding cessation, lethargy, muscle paralysis and ultimately death by activating the ryanodine receptor (Cao et. al., 2010 \& Lahm et. al., 2005). Additionally, because of hasn't been found to exhibit cross-resistance with other commercial insecticides (Wang et al. 2010, Sial et. al., 2010) and low ecotoxicology (Lahm et. al., 2007 and Jia et al. 2011), chlorantraniliprole is an excellent alternative to broad-spectrum insecticides in Integrated Pest Management (IPM) programs where commercial standards are no longer effective because of resistance (Lai et. al., 2011)..

Thiamethoxam is a broad spectrum neonicotenoid contact insecticide. Neonicotinoids interfere with the nicotinic acetylcholine receptor and therefore have specific activity against the insect nervous system (Maienfisch et. al., 2001). This unique mode of action makes them highly desirable for controlling insects that are developing resistance to conventional organophosphate, carbamate, and pyrethroid insecticides (Maienfisch et. al., 1999). Thiamethoxam also has minimal effects on beneficial insects, low toxicity toward mammals, and does not produce teratogenic or 
mutagenic effects (Lawson et. al., 1999). Because of this selective activity, thiamethoxam has been evaluated as a seed treatment for several major field crops, including cotton (Arthur et. al. 2004).

Novaluron a relatively new chitin synthesis inhibitor that inhibits the chitin formation on larvae of various insects (Lepidoptera, Coleoptera, Homoptera and Diptera). It has a potent insecticidal activity against several important foliage feeding insect pests (Cutler et. al., 2005) and very low toxicity to mammals, birds and earthworms. By inhibiting chitin formation, novaluron selectively targets immature insect stages, causing abnormal endocuticular deposition abortive molting (Rachid et. al. 2009).

In order to reduce the pesticide hazards and the development of resistant populations, insect control should be accomplished with fewer applications at lower doses. This aim might be realized, for example, by combining toxicants (conventional insecticides) chlorpyrifos-methyl and methomyl with other control agents with specific mode of action, such as chlorantraniliprole, thiamethoxam and novaluron (nonconventional insecticides, which considered new safe compounds). The efficiency of this insecticides alone and binary mixtures were investigated on cotton plants, applied at $1 / 2$ and $1 / 4$ recommended rates against the cotton leafworm $S$. littoralis, during the cotton seasons of 2011 and 2012 at Etay Elbaroud Agricultural Research Station, El-Beheira Governorate.

\section{MATERIALS AND METHODS}

\section{Tested compounds}

1. Coragen $20 \%$ SC (chlorantraniliprole). It was provided by DU PONT DU NEMOURS Company.

2. Actara $25 \%$ WG (thiamethoxam). It was provided by Syngenta Company.

3. Roxy $10 \%$ EC (novaluron). It was provided by United Phosphorus Ltd.

4. Reldane $50 \%$ EC (chlorpyrifos-methyl). It was provided by Dow Agro Sciences.

5. Ceumyl $90 \%$ SP (methomyl). It was provided by Macca for Agriculture Development.

\section{Field strain of Spodoptera littoralis}

Egg-masses of Spodoptera littoralis were collected from cotton fields at ElBeheira Governorate and directly transferred to the laboratory. After hatching the egg-masses were reared according to El-Defrawi et. al., (1964) and $4^{\text {th }}$ instar of Spodoptera larvae used for the experimental method. 


\section{The semi-field trial}

Cotton experimental site was divided into $35 \times 4$ plots, each plot $1 / 100$ feddan $\left(42 \mathrm{~m}^{2}\right)$. Randomized complete blocks design was used with four replicates for each treatment. A series of concentrations in water for chlorpyrifos-methyl and methomyl (1/2\&1/4 field conc.) alone or mixed with (1/2\&1/4 field conc.) of chlorantraniliprole, thiamethoxam and novaluron were used. Field concentrations were $60 \mathrm{ml}, 60 \mathrm{gm}$, $200 \mathrm{ml}, 1000 \mathrm{ml}$ and $300 \mathrm{gm}$ for chlorantraniliprole, thiamethoxam, novaluron, chlorpyrifos-methyl and methomyl, respectively. Samples of treated leaves were randomly taken from each treatment to the laboratory where they were introduced to $4^{\text {th }}$ instar of Spodoptera larvae. Four replicates (each of 10 larvae were placed in clean jar) were used for each treatment. Spodoptera larvae allowed to feed treated leaves for 24 hours. Survivors were transferred with fresh treated cotton leaves to clean glasses and kept the same conditions for another 24 hours. Percentage mortalities were corrected according to Abbott's formula, (Abbott, 1925) and analyzed using cotoxicity factor equation $=[$ (observed $\%$ mortality-expected $\%$ mortality $) /$ expected $\%$ mortality] $\times 100$ (Mansour et. al., 1966).

\section{RESULTS AND DISCUSSION}

Toxicity of chlorpyrifos-methyl, methomyl, chlorantraniliprole, thiamethoxam and novaluron at two low concentrations ( $1 / 2 \& 1 / 4$ field recommended rates were tested against $4^{\text {th }}$ instar larvae of Spodoptera littoralis at two cotton seasons 2011 and 2012. Data in table (1) illustrated the percent mortality of tested insecticides alone at low concentrations. The results showed that, percent mortality of chlorpyrifos-methyl, methomyl, chlorantraniliprole, thiamethoxam and novaluron at1/2 field rates on 2011 cotton season, was $22.5,27.5,17.5,12.5$ and $12.5 \%$, respectively after 24 hours, while it was $72.5,52.5,90.0,57.5$ and $57.5 \%$, respectively after 48 hours. Percent mortality at $1 / 4$ field rates, was $17.5,17.5,22.5,2.5$ and $27.5 \%$, respectively after 24 hours, while it was $42.5,30.0,85.0,50.0$ and $50.0 \%$, respectively after 48 hours.

Concerning mortality percentage of chlorpyrifos-methyl, methomyl, chlorantraniliprole, thiamethoxam and novaluron at 1/2 field rates on 2012 cotton season, was $32.5,32.5,27.5,20.0$ and $20.0 \%$, respectively after 24 hours, while it was $72.5,70.0,50.0,57.5$ and $62.5 \%$, respectively after 48 hours. Percent mortality at $1 / 4$ field rates, was $27.5,27.5,20.0,12.5$ and $30.0 \%$, respectively after 24 hours, while it was $67.5,50.0,52.5,40.0$ and $62.5 \%$, respectively after 48 hours. After 72 hours, all insecticide mixtures give $100 \%$ mortality. 
Table. 1. \% Mortalities of Spodoptera larvae after application of different insecticides during 2011 and 2012 cotton season.

\begin{tabular}{|c|c|c|c|c|c|}
\hline \multirow{3}{*}{ Season } & \multirow{3}{*}{ Tested compounds } & \multicolumn{4}{|c|}{$\%$ mortality } \\
\hline & & \multicolumn{2}{|c|}{ After 24 hours } & \multicolumn{2}{|c|}{ After 48 hours } \\
\hline & & $\begin{array}{c}\text { At } 1 / 2 \text { field } \\
\text { rate }\end{array}$ & $\begin{array}{c}\text { At } 1 / 4 \text { field } \\
\text { rate }\end{array}$ & $\begin{array}{c}\text { At } 1 / 2 \text { field } \\
\text { rate }\end{array}$ & $\begin{array}{c}\text { At } 1 / 4 \text { field } \\
\text { rate }\end{array}$ \\
\hline \multirow[t]{5}{*}{2011} & Chlorpyrifos-methyl & 22.5 & 17.5 & 72.5 & 42.5 \\
\hline & Methomyl & 27.5 & 17.5 & 52.5 & 30.0 \\
\hline & Chlorantraniliprole & 17.5 & 22.5 & 90.0 & 85.0 \\
\hline & Thiamethoxam & 12.5 & 2.5 & 57.5 & 50.0 \\
\hline & Novaluron & 12.5 & 27.5 & 57.5 & 50.0 \\
\hline \multirow[t]{5}{*}{2012} & Chlorpyrifos-methyl & 32.5 & 27.5 & 72.5 & 67.5 \\
\hline & Methomyl & 32.5 & 27.5 & 70.0 & 50.0 \\
\hline & Chlorantraniliprole & 27.5 & 20.0 & 50.0 & 52.5 \\
\hline & Thiamethoxam & 20.0 & 12.5 & 57.5 & 40.0 \\
\hline & Novaluron & 20.0 & 30.0 & 62.5 & 62.5 \\
\hline
\end{tabular}

Under the same conditions, joint toxic action at two low concentrations (1/2 \& $1 / 4$ field recommended rates) of chlorpyrifos-methyl and methomyl with two low concentrations (1/2 \& $1 / 4$ field recommended rates) of chlorantraniliprole, thiamethoxam and novaluron was tested against $4^{\text {th }}$ instar of Spodoptera larvae. Data presented in tables $(2,3,4$ and 5$)$ summarized the expected \%mortality, observed $\%$ mortality and cotoxicity factor of tested insecticides and their binary mixtures. During 2011 cotton growing season, all tested insecticides mixtures have antagonistic effects (cotoxicity factors $<0$ ) after 24 and 48 hours (Tables 2 and 3), except for chlorpyrifos-methyl (1/2 F.R)/chlorantraniliprole (1/2 F.R) mixture, chlorpyrifos-methyl $(1 / 2 \quad$ F.R $) /$ thiamethoxam (1/2 $\quad$ F.R $)$ mixture and chlorpyrifos-methyl (1/4 F.R)/chlorantraniliprole (1/2 F.R) mixture exhibited potentiation or synergistic effects (cotoxicity factors were $+6.3,+7.1$ and +7.1 , respectively), after 24 hours. Methomyl (1/4 F.R)/thiamethoxam (1/4 F.R) mixture exhibited potentiation effects (cotoxicity factors was 12.5), while methomyl (1/4 F.R)/novaluron (1/2 F.R) mixture exhibited additive effects (cotoxicity factors was 0 ). At 2012 cotton season, after 24 hours (Table 4), only one [chlorpyrifos-methyl (1/2 F.R)/chlorantraniliprole (1/4 F.R) mixture] of 24 binary mixture tested showed potentiation effect. While the majority, 22 mixtures exhibited antagonistic effects, and only one exhibited additive effects [chlorpyrifos-methyl (1/2 F.R)/chlorantraniliprole (1/2 F.R) mixture]. After 48 hours (Table 5), all tested insecticides mixtures have antagonistic effects. These results 
were agreement with those obtained from Cutler et. al., (2005) and Jia et. al. (2011) they found that chlorantraniliprole, thiamethoxam and novaluron have a potent insecticidal activity against several important foliage feeding insect pests, and very low toxicity to nontarget organism. Because of haven't been found to exhibit cross resistance with other conventional insecticides and low ecotoxicology (Wang et al. 2010, Sial et. al., 2010), chlorantraniliprole, thiamethoxam and novaluron are excellent alternatives to broad-spectrum insecticides in Integrated Pest Management (IPM) programs where commercial standards are no longer effective because of resistance (Ishaaya et al. 1996, Lahm et. al. 2007 and Lai et. al., 2011).

Table. 2. Toxicity of chlorpyrifos-methyl in combination with chlorantraniliprole, thiamethoxam and novaluron against $4^{\text {th }}$ instar Spodoptera larvae at 2011.

\begin{tabular}{|l|c|c|c|c|c|c|}
\hline \multirow{2}{*}{ Mixtures (field rates) } & \multicolumn{2}{|c|}{ Expected \%mortality } & \multicolumn{2}{c|}{ Observed \%mortality } & \multicolumn{2}{c|}{ Cotoxicity factor } \\
\cline { 2 - 7 } & after 24 & after 48 & After 24 & After 48 & After 24 & After 48 \\
hours & hours & hours & hours & hours \\
\hline Chlorpyrifos-methyl1/2+ & & & & & & \\
\hline Chlorantraniliprole 1/2 & 40.0 & 162.5 & 42.5 & 72.5 & +6.3 & -55.4 \\
\hline Chlorantraniliprole 1/4 & 45.0 & 157.5 & 40.0 & 77.5 & -11.1 & -50.8 \\
\hline Thiamethoxam 1/2 & 35.0 & 130.0 & 37.5 & 70.0 & +7.1 & -46.2 \\
\hline Thiamethoxam 1/4 & 25.0 & 122.5 & 20.0 & 57.5 & -20.0 & -53.1 \\
\hline Novaluron 1/2 & 35.0 & 130.0 & 12.5 & 60.0 & -64.3 & -53.8 \\
\hline Novaluron 1/4 & 50.0 & 122.5 & 30.0 & 77.5 & -40.0 & -36.7 \\
\hline Chlorpyrifos-methyl1/4+ & & & & & & \\
\hline Chlorantraniliprole 1/2 & 35.0 & 132.5 & 37.5 & 70.0 & +7.1 & -46.8 \\
\hline Chlorantraniliprole 1/4 & 40.0 & 127.5 & 32.5 & 70.0 & -18.7 & -45.1 \\
\hline Thiamethoxam 1/2 & 30.0 & 100.0 & 22.5 & 52.5 & -25.0 & -47.5 \\
\hline Thiamethoxam 1/4 & 20.0 & 92.5 & 12.5 & 42.5 & -37.5 & -54.1 \\
\hline Novaluron 1/2 & 30.0 & 100.0 & 17.5 & 42.5 & -41.7 & -57.5 \\
\hline Novaluron 1/4 & 45.0 & 92.5 & 30.0 & 67.5 & -33.3 & -27.0 \\
\hline
\end{tabular}

Cotoxicity factor $=[($ observed $\%$ mortality-expected $\%$ mortality $) /$ expected $\%$ mortality $] \times 100$ (Mansour et. al., 1966). 
Table. 3. Toxicity of chlorpyrifos-methyl in combination with chlorantraniliprole, thiamethoxam and novaluron against 4th instar Spodoptera larvae at 2012.

\begin{tabular}{|c|c|c|c|c|c|c|}
\hline \multirow[t]{2}{*}{ Mixtures (field rates) } & \multicolumn{2}{|c|}{ Expected \%mortality } & \multicolumn{2}{|c|}{ Observed \%mortality } & \multicolumn{2}{|c|}{ Cotoxicity factor } \\
\hline & $\begin{array}{c}\text { after } 24 \\
\text { hours }\end{array}$ & $\begin{array}{c}\text { after } 48 \\
\text { hours }\end{array}$ & $\begin{array}{c}\text { After } 24 \\
\text { hours }\end{array}$ & $\begin{array}{c}\text { After } 48 \\
\text { hours }\end{array}$ & $\begin{array}{c}\text { After } 24 \\
\text { hours }\end{array}$ & $\begin{array}{c}\text { After } 48 \\
\text { hours }\end{array}$ \\
\hline \multicolumn{7}{|l|}{ Chlorpyrifos-methyl1/2 + } \\
\hline Chlorantraniliprole 1/2 & 60.0 & 122.5 & 60.0 & 80.0 & 00.0 & -34.7 \\
\hline Chlorantraniliprole 1/4 & 52.5 & 125.0 & 60.0 & 80.0 & +14.3 & -36.0 \\
\hline Thiamethoxam 1/2 & 52.5 & 130.0 & 47.0 & 87.5 & -10.5 & -32.7 \\
\hline Thiamethoxam 1/4 & 45.0 & 112.5 & 40.0 & 90.0 & -11.1 & -20.0 \\
\hline Novaluron $1 / 2$ & 52.5 & 135.0 & 40.0 & 77.5 & -22.8 & -42.6 \\
\hline Novaluron $1 / 4$ & 62.5 & 135.0 & 37.5 & 67.5 & -40.0 & -50.0 \\
\hline \multicolumn{7}{|l|}{ Chlorpyrifos-methyl1/4 + } \\
\hline Chlorantraniliprole 1/2 & 55.0 & 117.5 & 47.5 & 72.5 & -13.6 & -38.3 \\
\hline Chlorantraniliprole 1/4 & 47.5 & 120.0 & 30.0 & 60.0 & -36.8 & -50.0 \\
\hline Thiamethoxam $1 / 2$ & 47.5 & 125.0 & 30.0 & 62.5 & -36.8 & -50.0 \\
\hline Thiamethoxam 1/4 & 40.0 & 107.5 & 10.0 & 67.5 & -75.0 & -37.4 \\
\hline Novaluron $1 / 2$ & 47.5 & 130.0 & 32.5 & 60.0 & -31.6 & -53.8 \\
\hline Novaluron $1 / 4$ & 57.5 & 130.0 & 27.5 & 67.5 & -52.2 & -48.1 \\
\hline
\end{tabular}

Cotoxicity factor $=[($ observed $\%$ mortality-expected $\%$ mortality $) /$ expected $\%$ mortality $] \times 100$ (Mansour et. al., 1966).

Meanwhile, the use of conventional and nonconventional insecticide combinations would minimize the amount of conventional insecticides applied, reduce the cost of insecticides for controlling process and reduce the level of environmental pollutions (Korrat et al., 2012). Our findings are in agreement with those reported by other researchers, Ahmad (2004\&2009), Kassem and Zeid (1987) and Ibrahim and Barakat (1991) they found that, mixing carbamate and organophosphate compounds with chitin synthesis inhibitor did not show any synergistic effect against larvae of $S$. littoralis. Sherby et. al. (2010) found that the combination of spinosad with chlorpyrifos resulted in additive or antagonistic effect. Radwan et. al. (2009) reported that, spinosad and abamectin in combination with profenofos at most of the tested mixing ratios exerted an antagonistic action based on the co-toxicity factors calculated on the basis of $\mathrm{LC}_{50}$ values at 24 or/and $72 \mathrm{~h}$. The obtained results indicated that conventional/nonconventional insecticides mixtures had the combined advantages of quick speed of killing and a high level of safety. Moreover, these mixtures probably affected by the existing resistance mechanism to conventional insecticides (Korrat et. al., 2012). 

MIXTURES AGAINST COTTON LEAF WORM, SPODOPTERA LITTORALIS (BOISD.)

(LEPIDOPTERA: NOCTUIDAE) IN COTTON FIELDS

Table. 4. Toxicity of methomyl in combination with chlorantraniliprole, thiamethoxam and novaluron against 4th instar Spodoptera larvae at 2011.

\begin{tabular}{|l|c|c|c|c|c|c|}
\hline \multirow{2}{*}{ Mixtures (field rates) } & \multicolumn{2}{|c|}{ Expected \%mortality } & \multicolumn{2}{c|}{ Observed \%mortality } & \multicolumn{2}{c|}{ Cotoxicity factor } \\
\cline { 2 - 7 } & $\begin{array}{c}\text { after 24 } \\
\text { hours }\end{array}$ & $\begin{array}{c}\text { after 48 } \\
\text { hours }\end{array}$ & $\begin{array}{c}\text { After 24 } \\
\text { hours }\end{array}$ & $\begin{array}{c}\text { After 48 } \\
\text { hours }\end{array}$ & $\begin{array}{c}\text { After 24 } \\
\text { hours }\end{array}$ & $\begin{array}{c}\text { After 48 } \\
\text { hours }\end{array}$ \\
\hline Methomyl 1/2+ & & & & & & \\
\hline Chlorantraniliprole 1/2 & 45.0 & 142.5 & 27.5 & 60.0 & -38.9 & -57.9 \\
\hline Chlorantraniliprole 1/4 & 50.0 & 137.5 & 22.5 & 60.0 & -55.0 & -56.4 \\
\hline Thiamethoxam 1/2 & 40.0 & 110.0 & 32.5 & 65.0 & -18.8 & -40.9 \\
\hline Thiamethoxam 1/4 & 30.0 & 102.5 & 22.5 & 57.5 & -25.0 & -43.9 \\
\hline Novaluron 1/2 & 40.0 & 110.0 & 20.0 & 70.0 & -50.0 & -36.4 \\
\hline Novaluron 1/4 & 55.0 & 102.5 & 35.0 & 62.5 & -36.4 & -39.0 \\
\hline Methomyl 1/4+ & & & & & & \\
\hline Chlorantraniliprole 1/2 & 35.0 & 120.0 & 22.5 & 60.0 & -35.7 & -50.0 \\
\hline Chlorantraniliprole 1/4 & 40.0 & 115.0 & 20.0 & 47.5 & -50.0 & -58.7 \\
\hline Thiamethoxam 1/2 & 30.0 & 87.5 & 20.0 & 52.5 & -33.3 & -40.0 \\
\hline Thiamethoxam 1/4 & 20.0 & 80.0 & 22.5 & 47.5 & +12.5 & -40.6 \\
\hline Novaluron 1/2 & 30.0 & 87.5 & 30.0 & 57.5 & 00.0 & -34.3 \\
\hline Novaluron 1/4 & 45.0 & 80.0 & 37.5 & 62.5 & -16.7 & -21.9 \\
\hline
\end{tabular}

Cotoxicity factor $=[($ observed $\%$ mortality-expected $\%$ mortality $) /$ expected $\%$ mortality $] \times 100$ (Mansour et. al., 1966).

Table. 5. Toxicity of methomyl in combination with chlorantraniliprole, thiamethoxam and novaluron against 4th instar Spodoptera larvae at 2012.

\begin{tabular}{|l|c|c|c|c|c|c|}
\hline \multirow{2}{*}{ Mixtures (field rates) } & \multicolumn{2}{|c|}{ Expected \%mortality } & \multicolumn{2}{c|}{ Observed \%mortality } & \multicolumn{2}{c|}{ Cotoxicity factor } \\
\cline { 2 - 7 } & $\begin{array}{c}\text { after 24 } \\
\text { hours }\end{array}$ & $\begin{array}{c}\text { after 48 } \\
\text { hours }\end{array}$ & $\begin{array}{c}\text { After 24 } \\
\text { hours }\end{array}$ & $\begin{array}{c}\text { After 48 } \\
\text { hours }\end{array}$ & $\begin{array}{c}\text { After 24 } \\
\text { hours }\end{array}$ & $\begin{array}{c}\text { After 48 } \\
\text { hours }\end{array}$ \\
\hline Methomyl 1/2+ & & & & & & \\
\hline Chlorantraniliprole 1/2 & 60.0 & 120.0 & 37.5 & 70.0 & -37.5 & -41.7 \\
\hline Chlorantraniliprole 1/4 & 52.5 & 122.5 & 37.5 & 72.5 & -28.6 & -40.8 \\
\hline Thiamethoxam 1/2 & 52.5 & 127.5 & 30.0 & 72.5 & -42.9 & -43.1 \\
\hline Thiamethoxam 1/4 & 45.0 & 110.0 & 30.0 & 80.0 & -33.3 & -27.3 \\
\hline Novaluron 1/2 & 52.5 & 132.5 & 30.0 & 77.5 & -42.9 & -41.5 \\
\hline Novaluron 1/4 & 62.5 & 132.5 & 32.5 & 60.0 & -48.0 & -54.7 \\
\hline Methomyl 1/4+ & & & & & & \\
\hline Chlorantraniliprole 1/2 & 55.0 & 100.0 & 22.5 & 77.5 & -59.1 & -22.5 \\
\hline Chlorantraniliprole 1/4 & 47.5 & 102.5 & 27.5 & 80.0 & -42.1 & -22.0 \\
\hline Thiamethoxam 1/2 & 47.5 & 107.5 & 22.5 & 77.5 & -52.6 & -27.9 \\
\hline Thiamethoxam 1/4 & 40.0 & 90.0 & 12.5 & 62.5 & -68.8 & -30.6 \\
\hline Novaluron 1/2 & 47.5 & 112.5 & 40.0 & 70.0 & -15.8 & -37.8 \\
\hline Novaluron 1/4 & 57.5 & 112.5 & 22.5 & 50.0 & -60.9 & -55.6 \\
\hline
\end{tabular}

Cotoxicity factor $=[($ observed $\%$ mortality-expected $\%$ mortality $) /$ expected $\%$ mortality $] \times 100$ (Mansour et. al., 1966). 
Insecticide mixtures are now commonly used to control multiple and resistant insect pests. Whereas the use of potentiation mixtures is a useful strategy to combat insecticide resistance, the use of antagonistic mixtures exacerbates resistance problem. The potentiation mixtures are supposed to counteract a mechanism of metabolic detoxification only. Over time, mixtures can select other mechanisms of resistance to insecticides. Resistance to mixtures and their components should therefore be monitored regularly. For a season-long pest control, mixtures should be rotated with other insecticide classes.

\section{REFERENCES}

1. Abbott, W. S. 1925. A method for computing the effectiveness of an insecticide. J. Econ. Entomol. 18: 265-267.

2. Ahmad, M. 2004. Potentiation/antagonism of deltamethrin and cypermethrins with organophosphate insecticides in the cotton bollworm, Helicoverpa armigera (Lepidoptera: Noctuidae). Pestic. Biochem. and Physiol. 80 (1): 31-42.

3. Ahmad, M. 2009. Observed potentiation between pyrethroid and organophosphorus insecticides for the management of Spodoptera litura (Lepidoptera: Noctuidae). Crop Protection. 28 (3): 264-268.

4. Anonymous. 2010. The WHO recommended classification of pesticides by hazard and guidelines to classification 2009. WHO Publications, Geneva, Switzerland. pp. 60.

5. Arthur, F. H., B. Yue and G. E. Wilde. 2004. Susceptibility of stored-product beetles on wheat and maize treated with thiamethoxam: effects of concentration, exposure interval, and temperature. J. Stored Products Res. 40: 527-546.

6. Aydin, M.H. and M.O. Gürkan. 2006. The efficacy of spinosad on different strains of Spodoptera littoralis (Boisduval) (Lepidoptera: Noctuidae). Turk J. Biol. 30: 59.

7. Cao, G., Q. Lu, L. Zhang , F. Guo, G. Liang , K. Wua, K. A.G. Wyckhuys and Y. Guo. 2010. Toxicity of chlorantraniliprole to Cry1Ac-susceptible and resistant strains of Helicoverpa armigera. Pestic. Biochem. and Physiol. 98: 99-103.

8. Cutler, G. C., C D. Scott-Dupree, J. H. Tolman and C. R. Harris. 2005. Acute and sublethal toxicity of Novaluron, a novel chitin synthesis inhibitor, to Leptinotarsa decemlineata (Coleoptera: Chrysomelidae). J. of Pest Management Sci. 61: 10601068.

9. El-Defrawi, M. E., A. Toppozada, N. Mansour and M. Zeid. 1964. Toxicological studies on the Egyptian cotton leafworm, Prodenia litura. I. Susceptibility of 
different larval instar of Prodenia to insecticides. J. Econ. Entomol. 57 (4): 591593.

10. Ibrahim, N. M. and A. A. Barakat. 1991. Efficiency of some binary mixtures of chitin synthesis inhibitors and conventional insecticides against $S$. littoralis (Boisd.) larvae. Bull. Entomol. Soc. Egypt, Econ. Ser. 19: 173-181.

11. Ishaaya I., S. Yablonski, Z. Mendelson, Y. Mansour and A. R. Horowitz. 1996. Novaluron (MCW-275), a novel benzoylphenylurea, suppressing developing stages of lepidopteran, whitefly and leafminer pests. Proceedings of the Brighton Crop Protection Conference, Pests and Diseases. 3: 1013-102.

12. Jia, H., W.U. Shun-fan and Y. E. Gong-yin. 2011. Evaluation of Lethal Effects of Chlorantraniliprole on Chilo suppressalis and Its Larval Parasitoid, Cotesia chilonis. Agric. Sci. in China. 10: 1134-1138.

13. Kassem, S. M. I, and M. I. Zeid. 1987. Comparison of the insecticidal efficiency of certain insecticides and their mixtures with insect chitin inhibitors. Alexandria J. Agric. Res. 32 (3): 335-345.

14. Korrat, E. E. E., A. E. Abdelmonem, A. A. R. Helalia and H. M. S. Khalifa. 2012. Toxicological study of some conventional and nonconventional insecticides and their mixtures against cotton leaf worm, Spodoptera littoralis (Boisd.) (Lepidoptera: Noectudae). Ann. Agric. Sci. 57 (2): 145-152.

15. Lahm, G. P, T. M. Stevenson, T. P. Selby, J. H. Freudenberger, D. Cordova, L. Flexner, C. A. Bellin, C. M. Dubas, B. K. Smith, K. A. Hughes, J. Gary Hollingshaus, C. E. Clark and E. A. Benner. 2007. Rynaxypyr ${ }^{\mathrm{TM}}$ : a new insecticidal anthranilic diamide that acts as a potent and selective ryanodine receptor activator. Bioorgnic Medical Chem. Letters.17: 6274-6279.

16. Lahm, G. P, T. P. Selby, J. H. Freudenberger, T. M. Stevenson, B. J. Myers, G. Seburyamo, B. K. Smith, L. Flexner, C. E. Clark and D. Cordova. 2005. Insecticidal anthranilic diamides: a new class of potent ryanodine receptor activators. Bioorgnic Medical Chem. Letters. 15: 4898-4906.

17. Lai, T., J. Li and J. Su. 2011. Monitoring of beet armyworm Spodoptera exigua (Lepidoptera: Noctuidae) resistance to chlorantraniliprole in China. Pestic. Biochem. and Physiol. 101: 198-205.

18. Lawson, D. S., D. M. Dumbar, S. M. White, and N. Ngo. 1999.. ACTARATM 25 WG: control of cotton pests with a new neonicotenoid insecticide, thiamethoxam. In: Proceedings of the Beltwide Cotton Conferences, Cotton Insect Research and Control Conference. National Cotton Council of America, Memphis, TN, USA, pp. 1106-1110. 
19. Maienfisch, P. L., H. Huerlimann, A. Rindlisbacher, L. Gsell, H. Dettwiler, J. Haettenschwiler, E. Sieger and M. Walti. 2001. The discovery of thiamethoxam: a second-generation neonicotenoid. Pest Management Sci. 57: 165-176.

20. Maienfisch, P. L., L. Gsell and A. Rindlisbacher. 1999. Synthesis and insecticidal activity of CGA 293343-a novel broad spectrum insecticide. Pestic. Sci. 55: 351354.

21. Mansour, N. A., M. E. Eldefrawi, A. Toppozada, N. Mansour and M. Zeid. 1966. Toxicological studies on the Egyptian cotton leafworm, Prodenia litura. VI. Potentiation and Antagonism of Organophosphorus and Carbamate Insecticides. J. Econ. Entomol. 59: 307-311.

22. Pluschkell, U., A. R. Horowitz, P. G. Weintraub and I. Ishaaya. 1998. DPXMP062- a potent compound for controlling the Egyptian cotton leafworm Spodoptera littoralis (Boisd.). Pestic. Sci. 54: 85-90.

23. Rachid R., F. Z. Saci, H. Berrebbah and M. R. Djebar. 2009. Toxic Effects of Combined Molecule from Novaluron and Diflubenzuron on Paramecium caudatum. Am. Eur. J. Toxicol. Sci. 1: 74-80.

24. Radwan, H. S. A., M. E. Nassar, A. E. El-Shikh, M. A. A. Abd El-Razik. 2009. Joint action of bio-insecticides and their role in development of resistance in Spodoptera littoralis (Boisd.). Minufiya. J. Agric. Res. 34 (2), 775-788.

25. Sherby, S. M.: H. K. Abou-Taleb and N. A. Mansour. 2010. Ovicidal and larval activity of spinosad against Egyptian cotton leafworm. J. Pest Cont. Environ. Sci. 18 (1): 69-81.

26. Sial, A. A., J. F. Brunner and D. Doerr. 2010. Susceptibility of Choristoneura rosaceana (Lepidoptera: Tortricidae) to two new reduced-risk insecticides. J. Econ. Entomol. 103: 140-146.

27. Smagghe, G., B. Carton, W. Wesemael, I. Ishaaya and L. Tirry. 1999. Ecdysone agonists mechanism of action and application on Spodoptera species. Pestic. Sci. 55: 343-389.

28. Wang, X.L., X.Y. Li, A.D. Shen and Y.D. Wu. 2010. Baseline susceptibility of diamondback moth (Lepidoptera: Plutellidae) to chlorantraniliprole in China. J. Econ. Entomol. 103: 843-848. 


\section{سمية بعض المبيدات التقليدية وإلغير تقليدية ومخاليطها ضد دودة ورق القطن فى حقول القطن}

أحمد عبدالحكيم برانيه مبروك عبدالمنعم البسومى محمدسين محمد الخوالقه معهُ بحوث وقاية النباتات- محطة البحوث الزراعية بايتاى البارود- مركز البحوث الزراعية

أجـرى هـــا البحـث بمزرعـة محطـة البحـوث الزراعيـة بايتـاى البـارود خـلال موســى

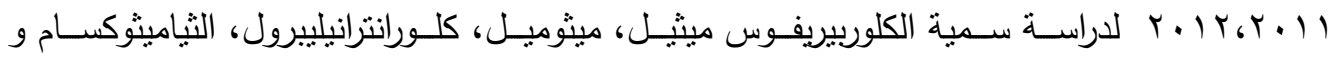

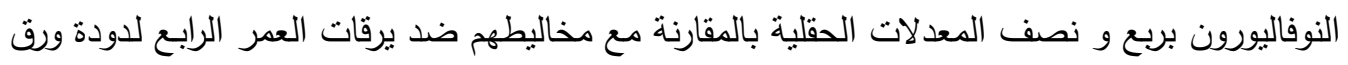

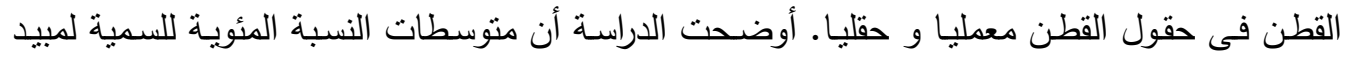

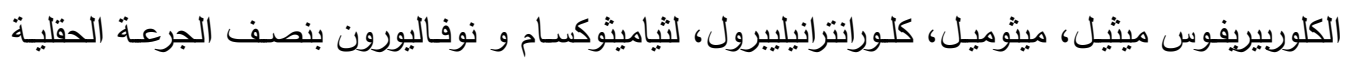

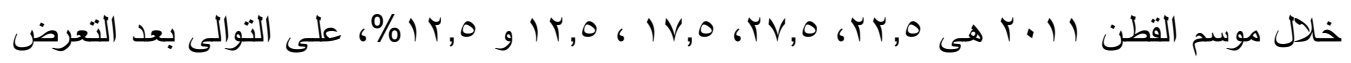

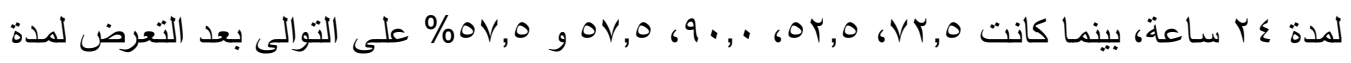

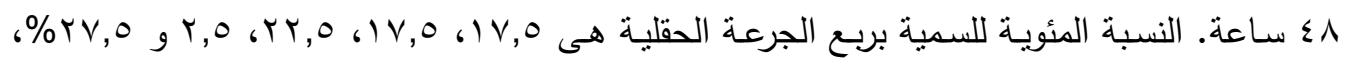

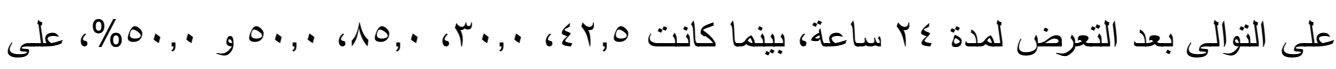

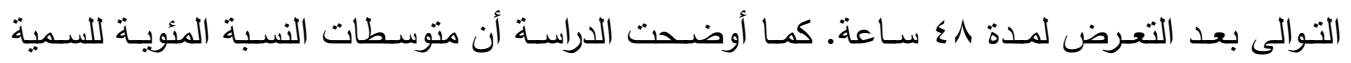

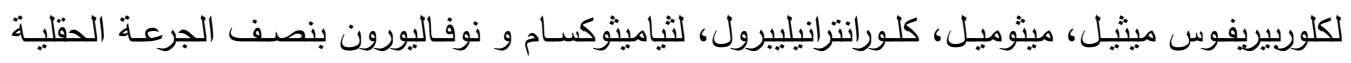

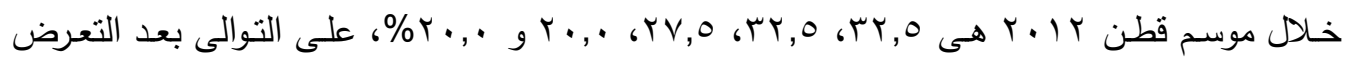

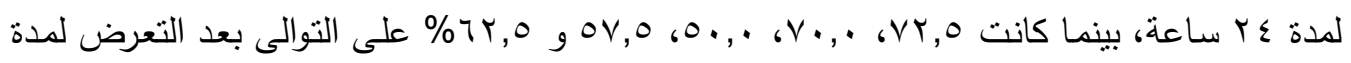

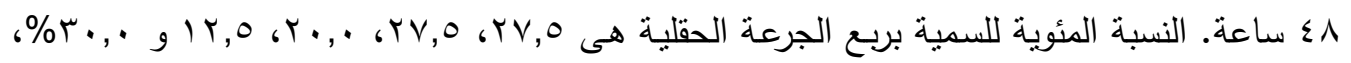

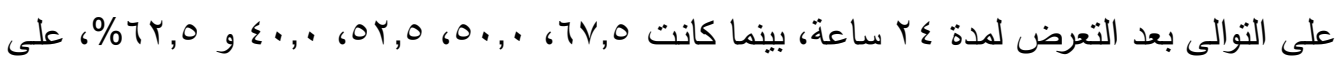

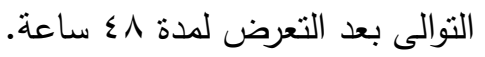

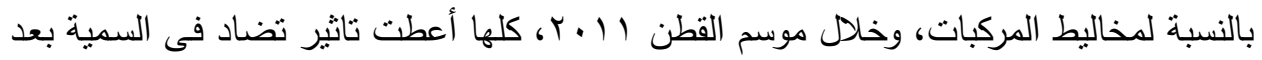

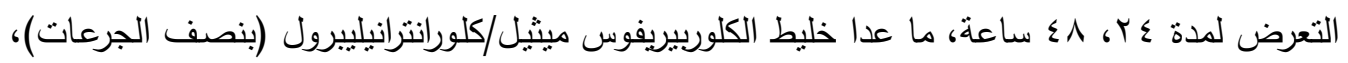

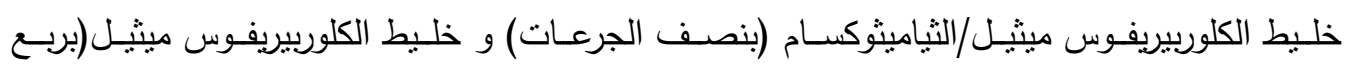
الجرعـة)/كلورانترانيلييرول (بنصف الجرعـة) و كذللك خليط الميثوميل/الثياميثوكسام (بربـع الجرعات) احدثت تاثير تتشيطى، بينما خليط الميثوميل (بربع الجرعة)/ النوفاليورون (بنصف الجرعة) ابدى تاثير

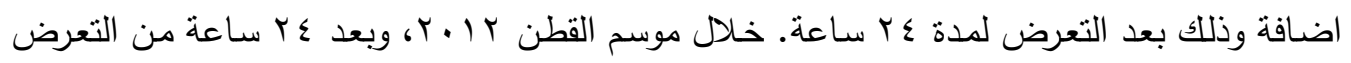

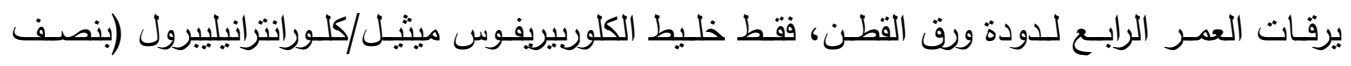

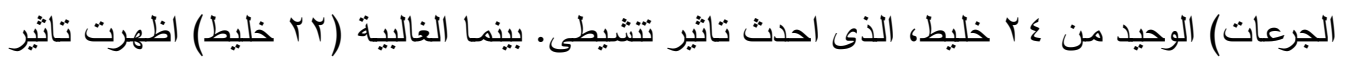

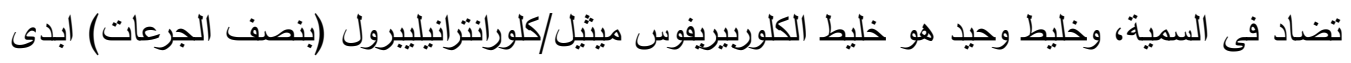

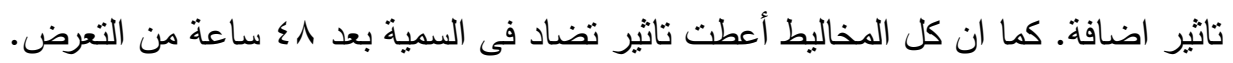

